\title{
Effort as a Mediator of the Relationship between English Learning Self-Efficacy and Reading Comprehension Performance in the EFL Field: A Longitudinal Study
}

\author{
Ariela Giladi $^{1}$, Meni Koslowsky ${ }^{2} \&$ Nitza Davidovitch ${ }^{3}$ \\ ${ }^{1}$ Department of Social Sciences, Ariel University, Ariel, Israel 40700 \\ ${ }^{2}$ Department of Psychology, Ariel University, Ariel, Israel 40700 \\ ${ }^{3}$ Department of Education, Ariel University, Ariel, Israel 40700 \\ Correspondence: Correspondence: Ariela Giladi, Department of Social Sciences, Ariel University, 65 Ramat \\ Hagolan St. Ariel, Israel 40700.
}

Received: June 15, 2021

doi:10.5430/ijhe.v11n1p114
Accepted: August 2, 2021

Online Published: August 9, 2021

URL: https://doi.org/10.5430/ijhe.v11n1p114

\begin{abstract}
English language skills are considered of great value in the labor market and in research. As such, learning English as a Foreign Language (EFL) is of great importance, especially for international students and employees working internationally. The goal of the present study was to explore student self-efficacy in language learning (LSE) and compare it to general self-efficacy (GSE) and effort (EF) as predictors of student English reading comprehension performance. The participants in this study were EFL students enrolled in academic English courses for one three-month academic semester. Using a longitudinal design, the sample of 265 participants completed three questionnaires: GSE, LSE, and EF scales at Time 1, the beginning of the semester. At Time 2, upon course completion, a reading comprehension test was given to all participants. Results indicate that LSE, and not GSE, is positively correlated with reading comprehension performance. Furthermore, the data showed that LSE is positively correlated with effort and that effort is positively correlated with reading comprehension performance. Further analysis revealed that effort mediates the relationship between LSE and reading comprehension performance. Our study will contribute to developing more effective teaching methods and provides EFL teachers with the necessary tools to predict and enhance student achievements. Implications and limitations for future research are discussed.
\end{abstract}

Keywords: language learning, self-efficacy, reading comprehension, effort, EFL

\section{Introduction}

\subsection{Background}

Proficient English language skills are considered of great value in the labor market and in research (Cui et al., 2018; Grenier, 2015; Li, H. Li, B, Fleisher, 2015; Wu \& Alrabah, 2020). Therefore, learning English as a Foreign Language (EFL) has become quite important, especially for international and science students and employees working in global settings. However, people widely differ in their ability to learn foreign languages (FL). Some individuals are capable of learning an additional language faster and better than others. This divergence in acquiring FL has encouraged psychologists to examine this issue both empirically and theoretically to pinpoint differences among individuals (Ehrman \& Oxford, 1995; Erton, 2010; Grigorenko et al., 2000; Liao \& Wang, 2018; Shvay et al., 2021). Several researchers have focused on language skills such as listening (Ableeva \& Lantolf, 2011), speaking (Davison et al., 2009), and reading (Guterman, 2002; Poehner \& Lantolf, 2013). While previous studies concentrated mainly on pedagogical applications of dynamic assessment, current research puts an emphasis on predicting student reading comprehension achievement in EFL and provides teachers with the necessary tools to enhance student performances. Language learning, particularly reading comprehension, is profoundly different from other types of learning and requires complex cognitive skills. As a result, there is growing interest in the scientific community to explore ways for enhancing performance in acquiring English language skills (Chou, 2019; Mantik \& Choi, 2018; Nicholson, 2013). The purpose of the present study was to examine student self-efficacy in language learning (LSE), in contrast with general self-efficacy (GSE) and effort as predictors of student English reading comprehension performance. More 
specifically, the study here examines effort as a potential mediator between LSE and reading comprehension performance.

\subsection{Self-Efficacy}

Drawn from the Social Cognitive Theory (Bandura, 1997), self-efficacy (SE) is defined as "a person's judgment of his or her abilities to organize and to execute courses of action necessary to achieve designated types of performances"' (Swanson, 2014, p. 7). More specifically, SE focuses on the learners' beliefs about whether they have the required capabilities to fulfill a task (Bandura, 1977). Furthermore, Bandura (1986) asserted that SE beliefs operate as an incentive factor for increasing motivation, action, and effort. Hence, it is suggested that positive experiences help build strong confidence in one's abilities, whereas failures tend to undermine and weaken a person's self-efficacy. Therefore, individuals are prone to engage in activities for which they have high SE and are less likely to participate in those for which they have low SE. In the framework of this study, we are interested in general self-efficacy (GSE), which can be defined as "one's belief in one's overall competence to effect requisite performances across a wide variety of achievement situations" (Eden, 2001, p. 75). Recent studies point to positive outcomes in individuals with higher expectations of competency in various areas in life, such as health, behavior, and learning (Décieux et al., 2020).

Educational psychology introduces SE as an essential factor influencing education-related success (Bandura, 1977; Bandura, 1986; Schunk, 1991; Shi, 2016). Mills, Pajares, and Herron (2007, p. 417) point out that "students' self-efficacy beliefs, and the judgments they hold about their capability to organize and execute the courses of action required to master academic tasks powerfully affect their academic performance in various ways." Likewise, findings from a meta-analysis of SE research (Multon, Brown, and Lent, (1991)) showed a positive relationship between self-efficacy beliefs and academic performance. Graham and Weiner's (1996) review of motivational research revealed similar results by showing that SE consistently predicted academic performance better than other motivational constructs. Lee and Jonson-Reid (2016) pointed out that academic SE influences the student's task choices, the effort expended, and determination in overcoming obstacles, which affects academic performance. The extensive research on the relationship between SE and academic achievement indicates a potentially strong influence of student self-perception of academic potential on academic behavior and performance.

\subsection{Learning Self- Efficacy and Reading Comprehension in Foreign Language Learning}

According to Bandura (1997), SE is domain-specific, and success depends on task difficulty. Hence, SE may vary in different contexts. Foreign language learning is different from other types of learning and requires complex skills to achieve proficiency. Reading comprehension is defined as "the process of simultaneously extracting and constructing meaning through interaction and involvement with written language" (Sweet \& Snow, 2003, p. 10). Additionally, Jung (2007, p. 56) clarifies that "text comprehension processes involve both top-down and bottom-up processes... [and they] operate in an interactive way". Moreover, Jung-Beeman and Chiarello (1998, p. 2) maintain that language comprehension is a 'complex mosaic' in which all components (right- and left hemispheres) must co-operate for complete comprehension. Another study on students' EFL reading rates indicates that from an information processing perspective, building automaticity on lower-level processes is necessary to allow readers to allocate more cognitive resources for higher-level processes (X. Chen et al., 2018). As such, the complexity of foreign language learning requires more empirical investigation. Several self-efficacy studies in this area explore its interrelationship with other variables in language learning (Baleghizadeh \& Mortazavi, 2014; Huang \& Chang, 1998; Matthews, 2010; Mills et al., 2007). A growing body of research is devoted to the role of SE in EFL contexts (P. H. P. Hsieh \& Schallert, 2008; Jabbarifar, 2011; Swanson, 2014).

Interestingly, according to Matthews (2010), past research has suggested that many foreign language students report low self-efficacy for language learning (Dornyei, 1994; Oxford \& Shearin, 1994). Oxford and Shearin indicate that this is due to the fact that many second language (L2) students' feel lost in the language class' (1994, p. 21). Moreover, Hsieh and Schallert (2008, p. 515) assert that 'students often perceive that foreign language learning is difficult and that only those with a special gift can do well.' Earlier research confirmed that 'students arrive at the task of language learning with definite preconceived notions of how to go about it' (Horwitz, 1988, p. 293). Hence, learners' predetermined beliefs about language learning likely affect the way they learn a foreign language. As such, it is expected that developing students' strong sense of self-efficacy in language learning will simultaneously reduce their expectations of failure and increase the student's perceived capability, which may improve outcome. Nevertheless, despite the strong correlation between GSE and higher performance suggested by the literature, in this study, we chose to differentiate between GSE and LSE, as a person may have low efficacy in language learning but may have high GSE in other subjects. Due to the complex process of language learning, compared to other subjects, 
and its effect on self-efficacy, we hypothesized that LSE, but not GSE, will positively correlate with English reading comprehension performance.

\subsection{LSE in STEM Students}

We suggest that there will be differences between LSE in science, technology, engineering, and mathematics (STEM) students and students majoring in social sciences and humanities. We do not imply that the field of study (i.e., STEM vs. social science) alone affects student LSE, but rather that the unique characteristics of those who choose a specific field may explain the variation. Since admission to STEM departments is relatively competitive and requires higher proficiency and skills, students who have been accepted may possess more positive attitudes toward their capabilities. This higher SE may, in turn, motivate them to put in more effort and improve their English, thus resulting in higher LSE. Indeed, previous reports show that STEM students have more positive attitudes and interest in improving their English than art students (Thang et al., 2011). Moreover, in a study conducted in Malaysia's University about the relationship between anxiety, attitude, and motivation in learning English as a second language, findings show that STEM students express a higher positive attitude towards learning English than non-STEM students (Jain \& Sidhu, 2013). In addition, a recent study on the relationship between writing self-efficacy and proficiency in English as a second language found that STEM students had significantly higher writing self-efficacy than those in social sciences (Raoofi et al., 2017). Therefore, we suggest examining this sub-group of STEM students to understand whether the associations expected here will be verified empirically.

\subsection{Language Learning Effort}

Another critical component influencing students' achievements is the effort they are willing to put into the learning process. However, despite its importance in educational research, there is still a lack of a standardized definition (Karabıyık \& Mirici, 2018). The prevalent definitions in the literature refer to effort as the overall amount of exertion expended in the studying process (Elliot et al., 1999; Zimmerman \& Risemberg, 1997). Other sets of definitions relate to student desire and the energy they expend in fulfilling the formal academic requirements (Carbonaro, 2005) and the actions taken by students in improving their learning skills (Utami et al., 2015). Karabiyik and Mirici (2018, p. 374) define foreign language learning effort as "the amount of individual resources students invest in the act of learning a foreign language and characterized by in-class and out-of-class endeavors in which students engage to fulfill the process of learning a foreign language." According to Gardner (2001), second language (L2) acquisition requires time, effort, and persistence and stands as a facet of motivation. Utami et al., (2015) explain that effort rises from the motivation process and expresses a form of behavioral activity involved in the learning process.

Past literature shows inconsistencies regarding the relationship between effort and academic achievement. Some studies suggest a positive relationship between the two variables (Carbonaro, 2005; Shih, 2019; Stewart, 2008), while others found a negative association (Chassie et al., 2004; Li, 2012). More recent works in the language learning effort field worldwide have uncovered a positive relationship between effort and achievement in foreign languages (Karabıyık \& Mirici, 2018). Research indicates that successful foreign language learning is not merely the product of intelligence and aptitude and that effort made to learn the language is also an essential factor. Individual effort is affected by a range of attitudinal variables (Ryan, 2010). According to Richard (2018), motivated L2 learners are goal-directed, persistent, and expend much effort. Therefore, students who wish to attain higher levels of skill perceive effort as necessary to achieve their goals. Hsieh and Kang (2010) found that Korean EFL students with high self-efficacy ascribed their success to internal components such as effort more than low self-efficacy students, thus showing a clear association between high SE and effort. Therefore, we hypothesized that LSE is positively correlated with effort and that effort will be positively correlated with reading comprehension performance in English.

Woodworth's (1928) stimulus-organism-response (S-O-R) model includes a mediation formulation that suggests "the effects of stimuli on behavior are mediated by various transformation processes internal to the organism" (Woodworth, as cited in Baron \& Kenny, 1986, p. 1176). As such, this internal response to a stimulus may lead one to perform in a particular fashion. For example, studies have reported that effort can be considered a mediator between different motivational constructs and academic performance (Elliot et al., 1999; Goodman et al., 2011; Schwinger et al., 2009). As such, we hypothesize that effort mediates the relationship between LSE and reading comprehension performance in English.

\subsection{Developing New Scales}

In their studies, investigators often wish to measure a wide range of constructs. However, completing a large packet of questionnaires can be a dull or irritating task for participants. Moreover, long questionnaires can lead to errors, 
missing data, and a general resentment to participate in future studies (Schmidt et al., 2003). Given these kinds of practical problems, researchers often create shorter forms of longer questionnaires such as the mini IPIP (Donnellan et al., 2006) and the NGSE: the new general self-efficacy scale (G. Chen et al., 2001). Taking these concerns into account, we developed The Language Learning SE scale (LSE), a short questionnaire with five items intended to measure student self-efficacy in the foreign language acquisition process.

Although research on effort in educational psychology and its importance for foreign and L2 learning is well known, it is rarely investigated (Richard, 2018). Furthermore, Richard (2018) points out that when it has been investigated, the study's operationalization may have been poorly conceived and, therefore, potential problems with the measures were identified. Similarly, Karabiyık and Mirici (2018) assert that despite attempts in quantifying foreign language learning effort, the measures tested seem to have reliability and validity issues. As such, the lack of a standardized scale in the field led us to develop The EFL Reading Comprehension Effort scale (EF), a short five-item questionnaire to measure the degree to which the student is willing to exert effort for acquiring a foreign language and, more specifically in EFL, reading comprehension tasks.

In summary, the purpose of the present study was to examine student self-efficacy in language learning and effort as predictors of student reading comprehension performance in English.

Based on the above, the following hypotheses will be examined.

- Hypothesis 1: Language self-efficacy is positively correlated with reading comprehension performance.

- Hypothesis 2: Language self-efficacy is positively correlated with effort.

- Hypothesis 3: Effort is positively correlated with reading comprehension performance.

- Hypothesis 4: Effort mediates the relationship between language self-efficacy and reading comprehension performance.

\section{Method}

\subsection{Participants}

Using a longitudinal design, hypotheses were tested on 265 subjects using self-report questionnaires and reading comprehension tests. Subjects were Hebrew-speaking undergraduate students enrolled in an academic English course. After eliminating questionnaires with missing data, the cohort consisted of 90 men (37.3\%) and 151 women (62.7\%). Participants ranged in age from 19 to 56 years $(\mathrm{M}=26.4, \mathrm{SD}=6.04), 209$ of them (79.2\%) speak Hebrew as a native tongue, 24 speak Russian (9.1\%), 20 speak Arabic (7.6\%), 2 speak Amharic (0.8\%), and 9 speak other languages (3.4\%). The participants were students of Engineering (29.4\%), Social and Behavioral studies (28.3\%), and Health studies $(28.7 \%)$. Around $10 \%$ of the participants did not indicate a specific field of studies

\subsection{Measures}

The New General Self-Efficacy Scale (GSE) (G. Chen et al., 2001) comprises eight items with a scoring of 1 'strongly disagree' to 5 'strongly agree.' An example of an item in the scale is 'I will be able to achieve most of the goals that I have set for myself' (see Appendix A). Reliability, as measured with Coefficient alpha, was 0.89 .

The Language Learning Self-Efficacy Scale (LSE) is composed of five items with a scoring scale from 1 'strongly disagree' to 5 'strongly agree' reflecting the degree to which an individual evaluates their capability to learn a foreign language. An example GSE item is: 'I believe in my ability to learn English as a foreign language' (see Appendix B). Reliability, as measured with Coefficient alpha, was 0.85 .

The EFL Reading Comprehension Effort Scale (EF) is composed of five items with a scoring scale from 1 'almost never' to 5 'every day' reflecting the degree to which an individual is willing to put in effort in order to succeed in reading comprehension tasks in a foreign language. An example of an item is: 'I read English as a foreign language (books, newspapers, magazines)' (see Appendix C). Reliability, as measured with Coefficient alpha, was 0.74.

Reading Comprehension Test (RCT). An English reading comprehension test at the end of the semester prepared by the English department and designed for EFL students. It measures a student's ability to read a text and determine the main idea or essential message, and identify relevant supporting details and facts. It is composed of 13 questions (some of the questions have sub-questions) comprising multiple-choice questions, true/false, charts to fill in, and open questions. 


\subsection{Procedure}

IRB approval was obtained, and all ethical procedures were observed. Participants completed the above questionnaires voluntarily and anonymously in the framework of their academic English courses. For the pre-test, internal consistency reliability was examined for LSE and EF scales from 75 subjects. As this was a longitudinal study, EFL participants enrolled in an academic English course for one academic semester were assessed twice. At Time 1, 265 participants completed three questionnaires: GSE, LSE, and EF scales. At Time 2, three months later, a reading comprehension test was given to the participants who had completed the previous questionnaires (246 out of 265 participants completed the exams).

\section{Results}

\subsection{Preliminary Analyses}

For the pre-test, internal consistency reliability was tested on 75 students. The sample consisted of 36 men and 36 women (three did not respond) with a mean age of 25.5 years $(\mathrm{SD}=5.04)$. Mean on the LSE was $3.87(\mathrm{SD}=0.79)$ and mean on the $\mathrm{EF}$ was $2.47(\mathrm{SD}=0.96)$

\subsection{Main Study}

The EF, LSE, and GSE were administered at Time 1 and the reading comprehension test at Time 2 . The descriptive statistics for the measures are reported in Table 1.

Table 1. Descriptive Statistics for Study Variables (N=265)

\begin{tabular}{lccccc}
\hline \multicolumn{1}{c}{ Variable } & N & Min. & Max. & M & SD \\
\hline EFL Reading Comprehension Effort (EF) & 260 & 1.00 & 5.00 & 2.38 & 0.81 \\
Language Learning Self-Efficacy (LSE) & 261 & 1.60 & 5.00 & 3.64 & 0.85 \\
General Self-Efficacy (GSE) & 263 & 2.37 & 5.00 & 4.08 & 0.55 \\
Reading Comprehension Test Grade (RCT) & 246 & 35 & 96 & 68.72 & 11.16
\end{tabular}

For testing Hypothesis 1, language self-efficacy is positively correlated with reading comprehension performance, Pearson correlations were examined (see Table 2). Results showed no correlation between GSE and reading comprehension performance $(r=0.05, p>0.05)$, and a positive correlation with LSE $(r=0.19, p<0.01)$. Thus, results support Hypothesis 1. Analysis of the correlation between the scales LSE and EF showed the two were significantly associated $(r=0.49, p<0.01)$, supporting Hypothesis 2 that language self-efficacy is positively correlated with effort. According to Hypothesis 3, effort is positively correlated with reading comprehension performance. Indeed, the Pearson correlation (see Table 2) was significant and positive $(r=0.29, p<0.01)$, indicating that participants with higher effort levels received higher scores in reading comprehension tests. Hence, Hypothesis 3 was also supported.

Table 2. Pearson Correlations for Study Variables $(\mathrm{N}=265)$

\begin{tabular}{rlcccc}
\hline \multicolumn{1}{c}{ Measure } & 1. & 2. & 3. & 4. \\
\hline 1. Language Learning Self-Efficacy (LSE) & 1 & & & \\
2. General Self-Efficacy (GSE) & $\mathbf{0 . 3 0 3 * *}$ & 1 & & \\
3. EFL Reading Comprehension Effort (EF) & $\mathbf{0 . 4 9 1 * *}$ & $\mathbf{0 . 2 2 7 * *}$ & 1 & \\
4. & Reading Comprehension Test Grade (RCT) & $\mathbf{0 . 1 8 8 * *}$ & 0.054 & $\mathbf{0 . 2 8 8 * *}$ & 1 \\
\hline
\end{tabular}

$\mathrm{P}<0.01$ (2-tailed)**

Finally, after determining that LSE was correlated with effort and effort was correlated with reading comprehension, effort was tested as a mediator. To examine this hypothesis, we used the Process procedure (model 4) in SPSS (Hayes, 2013). In line with our hypothesis, results showed that effort significantly mediated the association between LSE and reading comprehension (standardized $b=0.1451,95 \%$ CI $(0.0668,0.2339)$ ) and the direct effect of LSE on performance was no longer significant $(b=0.84, t=0.91, p>0.05$, CI $(-0.98,2.66))$. Hence, Hypothesis 4 , that effort mediates the association between LSE and reading comprehension performance, was supported. 


\subsection{Sub-Group Analysis}

As the next step, we wished to examine the correlation between LSE and scores in reading comprehension tests in a sub-group consisting of STEM students. The findings from 96 participants who major in STEM (out of the 265 subjects) are presented in Table 3. The LSE-RCT correlation was indeed higher $(\mathrm{r}=0.35, \mathrm{p}<0.01)$. Moreover, similar to results in the larger group, LSE correlated with effort $(r=.42, p<.01)$ and effort correlated with reading comprehension $(r=0.36, p<0.01)$. Finally, we examined effort as a mediator in the STEM sub-group. Indeed, effort significantly mediated the association between LSE and reading comprehension (standardized $b=0.1221,95 \%$ CI $(0.0251,0.2418))$. Unlike in the large cohort, the direct effect of LSE on reading performance remained significant in the STEM group $(\mathrm{b}=3.24, \mathrm{t}=2.25, \mathrm{p}<0.05$, CI $(0.38,6.11)$ ).

Table 3. Pearson Correlations for Study Variables in the STEM sub-group ( $N=96)$

\begin{tabular}{|c|c|c|c|c|}
\hline Measure & 1. & 2. & 3. & 4. \\
\hline 1. Language Learning Self-Efficacy (LSE) & 1 & & & \\
\hline 2. General Self-Efficacy (GSE) & $0.281 * *$ & 1 & & \\
\hline 3. EFL Reading Comprehension Effort (EF) & $0.421 * *$ & $0.251 *$ & 1 & \\
\hline 4. Reading Comprehension Test Grade (RCT) & $0.346 * *$ & 0.056 & $0.362 * *$ & 1 \\
\hline
\end{tabular}

\section{Discussion}

The purpose of the current study was to explore ways to enhance performance in the EFL field further. As hypothesized, the findings presented here showed no correlation between general self-efficacy to reading comprehension performance. However, we found a positive correlation with learning self-efficacy, such that participants with higher levels of learning self-efficacy received higher scores in reading comprehension tests. This finding is consistent with many other studies that describe the complex processes involved in learning to read and comprehend a foreign language and how this skill is related to self-efficacy (X. Chen et al., 2018; Jung, 2007; Jung-Beeman \& Chiarello, 1998; Sweet \& Snow, 2003).

The second hypothesis examined the relationship between the LSE and EF scales. Results showed that language self-efficacy and effort are positively correlated and that LSE predicts those who are willing to put effort into English reading comprehension learning. Again, as mentioned above, these findings are consistent with studies associating language self-efficacy and effort (Okuyan et al., 2018). Results supporting the third hypothesis showed that effort is positively correlated with reading comprehension performance. Subjects who reported putting in high levels of effort received better scores in reading comprehension tests. Our findings support recent literature reporting the association between effort and learning foreign languages (Karabıyık \& Mirici, 2018).

In line with our fourth hypothesis, our results showed that effort mediates the relationship between language self-efficacy and reading comprehension performance. Our findings are consistent with previous research showing effort to be a mediator between different motivational constructs and academic performances (Elliot et al., 1999; Goodman et al., 2011; Schwinger et al., 2009). However, despite research suggesting effort as a mediator in academic success, to the best of our knowledge, no previous studies have examined effort as a mediator in the EFL field and, more specifically, in reading comprehension tasks. Thus, our study emphasizes the importance of increasing student learning self-efficacy and points to a connection between higher LSE and effort as leading to higher performance.

To further investigate the major findings in our study, we chose to replicate the analysis on a sub-group of students who major in STEM. As expected, results showed that the correlation between LSE and grades was indeed higher. Thus, it is likely that students who have been accepted to such competitive departments possess more positive attitudes toward their abilities (Jain \& Sidhu, 2013; Thang et al., 2011), translating to higher English grades. This is consistent with a recent study on the association between writing self-efficacy and performance in English writing that revealed that science students had significantly higher writing self-efficacy than those in social sciences (Raoofi et al., 2017).

In addition to describing the importance of LSE in foreign language learning (Baleghizadeh \& Mortazavi, 2014; Matthews, 2010; Shi, 2016), we provide future researchers with crucial scales for evaluating student effort and SE in 
language learning. As such, our new measures may contribute to developing more effective teaching methods and provide EFL teachers and practitioners the necessary tools to predict and enhance student achievements in the field.

\section{Limitations and Recommendation for Future Research}

This research has several limitations that we believe are important to discuss. The first issue concerns the samples used. Our analyses were based on university-student samples, and future research should extend these results to other populations as well. Moreover, to enhance the reliability of our findings, we suggest conducting experimental research with a control group, in which the experimental group will receive tools to improve LSE and effort skills. In their intervention study, Brisson et al. (2017) showed a sustained impact on student competence beliefs, teacher-rated effort, and test scores in mathematics in a real-life learning setting. Hence, more intervention studies in the EFL field are recommended for examining English performance in other areas such as writing and speaking.

A few limitations should be noted regarding the LSE and EF scales. It is accepted that errors, respondent fatigue, and content redundancy are often reduced by administering shorter forms, thereby increasing measure reliability and validity (Schmidt et al., 2003; Viswesvaran et al., 2014). Nevertheless, some participants might need more items than others to reach the appropriate mindset for responding to the underlying factor being measured, and, as such, the use of fewer items may lead to measurement errors. However, Donnellan et al. (2006) point out regarding questionnaires' length that many study participants hold the view that the shorter the testing time, the better the study. This assumption supports our goal to create effective measures with relatively few items. In closing, we note that creating short but valid tools may lead to subtle improvements in participants' experience and motivation in educational and psychological research.

\section{Practical Suggestions and Applications to Teaching}

As our research shows, it is essential that teachers develop and sustain student learning self-efficacy and effort. We suggest the following for achieving these goals. (1) Feedback: teachers should give students frequent and specific feedback. By focusing on student improvements (even minor ones), teachers strengthen the student's sense of self-efficacy and improve motivation for learning (Schunk \& Zimmerman, 1997). (2) Self-reflection: by using self-reflection for evaluation, students can measure progress and change their goals or set new ones to match their progress (Schunk, 2003). (3) Plan individualized tasks: provide moderated and individualized tasks, i.e., not too simplistic, but also not overly complex, as it might discourage some students (Margolis \& Mccabe, 2006). Consequently, even weaker students could experience a sense of accomplishment and gradually build their confidence and learning self-efficacy. (4) Goals and effective strategies: set specific goals and provide practical strategies to use during learning. A clear work plan may motivate students to exert more effort in the learning process and, as such, enhance performance. (5) A supportive environment is essential since learning a foreign language involves preconceived notions regarding learning abilities. As such, a supportive and encouraging environment in the classroom can form the basis for developing students' learning self-efficacy, which, in turn, can affect effort and achievement.

\section{Declaration of Interest Statement}

We have no conflicts of interest to disclose.

\section{References}

Ableeva, R., \& Lantolf, J. (2011). Mediated dialogue and the microgenesis of second language listening comprehension. Assessment in Education: Principles, Policy and Practice, 18(2), 133-149. https://doi.org/10.1080/0969594X.2011.555330

Baleghizadeh, S., \& Mortazavi, M. (2014). The impact of different types of journaling techniques on EFL learners' self-efficacy. PROFILE Issues in Teachers' Professional Development, 16(1), 77-88. https://doi.org/10.15446/profile.v16n1.37184

Bandura, A. (1977). Self-efficacy: Toward a unifying theory of behavioral change. Psychological Review, 84(2), 191-215. https://doi.org/10.1037/0033-295x.84.2.191

Bandura, A. (1986). Social foundations of thought and action: a social cognitive theory / Albert Bandura. In Englewood Cliffs, N.J: Prentice-Hall, 1986. xiii, 617.

Bandura, A. (1997). Collective efficacy. In Self-efficacy: The exercise of control, 50, 477-525. https://doi.org/10.1177/0957154X9400501708 
Baron, R. M., \& Kenny, D. A. (1986). The moderator-mediator variable distinction in social psychological research: Conceptual, strategic, and statistical considerations. Journal of Personality and Social Psychology. https://doi.org/10.1037//0022-3514.51.6.1173

Berliner, D. C. [Ed], \& Calfee, R. C. [Ed]. (1996). Handbook of educational psychology. In Handbook of educational psychology.

Brisson, B. M., Dicke, A. L., Gaspard, H., Häfner, I., Flunger, B., Nagengast, B., \& Trautwein, U. (2017). Short Intervention, Sustained Effects: Promoting Students' Math Competence Beliefs, Effort, and Achievement. American Educational Research Journal. https://doi.org/10.3102/0002831217716084

Carbonaro, W. (2005). Tracking, students' effort, and academic achievement. Sociology of Education. https://doi.org/10.1177/003804070507800102

Chassie, M. B., O’Conner, E. J., \& Walther, F. (2004). Expended effort and academic performance. Testing of Psychology, 7(4), 231-233. https://doi.org/10.1207/s15328023top0704_10

Chen, G., Gully, S. M., \& Eden, D. (2001). Validation of a New General Self-Efficacy Scale. Organizational Research Methods. https://doi.org/10.1177/109442810141004

Chen, X., Li, H., \& Gui, M. (2018). Instructional Effects of Syntactic Parsing on Chinese College Students' EFL Reading Rates. Journal of Education and Training Studies, 6(11), 176. https://doi.org/10.11114/jets.v6i11.3470

Chou, M. H. (2019). Predicting self-efficacy in test preparation: Gender, value, anxiety, test performance, and strategies. Journal of Educational Research. https://doi.org/10.1080/00220671.2018.1437530

Cui, S., Pan, K., \& Ye, Y. (2018). Language Ability or Personality Works?: The Return to Possessing a Global English Test Certificate for College Graduates in China. ECNU Review of Education. https://doi.org/10.30926/ecnuroe2018010204

Davison, C., Leung, C., Hill, K., \& Sabet, M. (2009). Dynamic Speaking Assessments. TESOL Quarterly, 43(3), 537-545. https://doi.org/10.1002/j.1545-7249.2009.tb00251.x

Décieux, J. P., Sischka, P. E., Schumacher, A., \& Willems, H. (2020). Psychometrical Properties of a French Version of the General Self-Efficacy Short Scale (ASKU). Swiss Journal of Psychology. https://doi.org/10.1024/1421-0185/a000233

Donnellan, M. B., Oswald, F. L., Baird, B. M., \& Lucas, R. E. (2006). The Mini-IPIP scales: Tiny-yet-effective measures of the Big Five factors of personality. Psychological Assessment. https://doi.org/10.1037/1040-3590.18.2.192

Dornyei, Z. (1994). Motivation and Motivating in the Foreign Language Classroom. The Modern Language Journal, 78(3), 273-284. https://doi.org/10.1111/j.1540-4781.1994.tb02042.x

Eden, D. (2001). Means efficacy: External sources of general and specific subjective efficacy. In Work motivation in the context of a globalizing economy.

Ehrman, M. E., \& Oxford, R. L. (1995). Cognition Plus - Correlates of Language-Learning Success. Modern Language Journal, 79(1), 67-89. https://doi.org/10.1111/j.1540-4781.1995.tb05417.x

Elliot, A. J., McGregor, H. A., \& Gable, S. (1999). Achievement goals, study strategies, and exam performance: A mediational analysis. Journal of Educational Psychology. https://doi.org/10.1037/0022-0663.91.3.549

Erton, I. (2010). Relations between personality traits, language learning styles and success in foreign language achievement. Hacettepe Egitim Dergisi, 38, 115-126.

Gardner, R. C. (2001). Integrative Motivation and Second Language Acquisition BT - MOTIVATION AND SECOND LANGUAGE ACQUISITION, Dornyei, Zoltan, \& Schmidt, Richard [Eds], Honolulu: U Hawai'i Press, 2001, pp 1-19. In MOTIVATION AND SECOND LANGUAGE ACQUISITION, Dornyei, Zoltan, \& Schmidt, Richard [Eds], Honolulu: U Hawai'i Press, 2001, 1-19.

Goodman, S., Jaffer, T., Keresztesi, M., Mamdani, F., Mokgatle, D., Musariri, M., Pires, J., \& Schlechter, A. (2011). An investigation of the relationship between students' motivation and academic performance as mediated by effort. South African Journal of Psychology. https://doi.org/10.1177/008124631104100311

Grenier, G. (2015). The value of language skills. IZA World of Labor. https://doi.org/10.15185/izawol.205 
Grigorenko, E. L., Sternberg, R. J., \& Ehrman, M. E. (2000). A Theory-Based Approach to the Measurement of Foreign Language Learning Ability: The Canal-F Theory and Test. The Modern Language Journal, 84(3), 390-405. https://doi.org/10.1111/0026-7902.00076

Guterman, E. (2002). Toward dynamic assessment of reading: Applying metacognitive awareness guidance to reading assessment tasks. Journal of Research in Reading, 25(3), 283-298. https://doi.org/10.1111/1467-9817.00176

Hayes, A. (2013). Introduction to mediation, moderation, and conditional process analysis (Methodology in the Social Sciences) (The Guilford Press, New York, NY). In New York, NY: Guilford. https://doi.org/978-1-60918-230-4

Horwitz, E. K. (1988). The Beliefs about Language Learning of Beginning University Foreign Language Students. The Modern Language Journal, 72(3), 283-294. https://doi.org/10.1111/j.1540-4781.1988.tb04190.x

Hsieh, P. H. P., \& Schallert, D. L. (2008). Implications from self-efficacy and attribution theories for an understanding of undergraduates' motivation in a foreign language course. Contemporary Educational Psychology, 33(4), 513-532. https://doi.org/10.1016/j.cedpsych.2008.01.003

Hsieh, P. P. H., \& Kang, H. S. (2010). Attribution and self-efficacy and their interrelationship in the Korean EFL context. Language Learning, 60(3), 606-627. https://doi.org/10.1111/j.1467-9922.2010.00570.x

Huang, S. C., \& Chang, S. F. (1998). Self-Efficacy in Learners of English as a Second Language: Four Examples. Journal of Intensive English Studies, 12, Fall.

Jabbarifar, T. (2011). The Importance Of Self-Efficacy And Foreign Language Learning In The 21st Century. Journal of International Education Research (JIER). https://doi.org/10.19030/jier.v7i4.6196

Jain, Y., \& Sidhu, G. K. (2013). Relationship between Anxiety, Attitude and Motivation of Tertiary Students in Learning English as a Second Language. Procedia - Social and Behavioral Sciences. https://doi.org/10.1016/j.sbspro.2013.07.072

Jung, E. H. (Sara). (2007). The Study of Second Language Text Comprehension and Measurement Issues, 62(3), 55-68. https://doi.org/10.15858/engtea.62.3.200709.55

Jung-Beeman, M., \& Chiarello, C. (1998). Complementary Right-and Left-Hemisphere Language Comprehension. In Current directions in psychological science: a journal of the American Psychological Society, 7(1), 2-8. https://doi.org/10.1111/1467-8721.ep11521805

Karabıyık, C., \& Mirici, İ. H. (2018). Development and validation of the foreign language learning effort scale for Turkish tertiary-level students. Kuram ve Uygulamada Egitim Bilimleri. https://doi.org/10.12738/estp.2018.2.0010

Lee, Y. S., \& Jonson-Reid, M. (2016). The Role of Self-Efficacy in Reading Achievement of Young Children in Urban Schools. Child and Adolescent Social Work Journal. https://doi.org/10.1007/s10560-015-0404-6

Li, H., Li, B., \& Fleisher, B. M. (2015). Language skills are critical for workers' human capital transferability among labor markets. Policy Brief.

Li, L. K. Y. (2012). A Study of the Attitude, Self-efficacy , Effort and Academic Achievement of CityU Students towards Research Methods and Statistics. Discovery SS Student E - Journal.

Liao, H. C., \& Wang, Y. H. (2018). Using comprehension strategies for students' self-efficacy, anxiety, and proficiency in reading English as a foreign language. Social Behavior and Personality: An International Journal. https://doi.org/10.2224/sbp.6648

Mantik, O., \& Choi, H. J. (2018). Scaffolded Think-Group-Share learning to enhance children's English learning performance. PROCEEDINGS OF THE 65th TEFLIN INTERNATIONAL CONFERENCE, 65(01).

Margolis, H., \& Mccabe, P. P. (2006). Improving self-efficacy and motivation: What to do, what to say. Intervention in School and Clinic. https://doi.org/10.1177/10534512060410040401

Matthews, P. H. (2010). Factors influencing self-efficacy judgments of university students in foreign language tutoring. Modern Language Journal, 94(4), 618-635. https://doi.org/10.1111/j.1540-4781.2010.01057.x

Mills, N., Pajares, F., \& Herron, C. (2007). Self-efficacy of college intermediate French students: Relation to achievement and motivation. Language Learning, 57(3), 417-442. https://doi.org/10.1111/j.1467-9922.2007.00421.x 
Multon, K. D., Brown, S. D., \& Lent, R. W. (1991). Relation of Self-Efficacy Beliefs to Academic Outcomes: A Meta-Analytic Investigation. Journal of Counseling Psychology, 38(1), 30-38. https://doi.org/10.1037/0022-0167.38.1.30

Nicholson, S. J. (2013). Influencing Motivation In The Foreign Language Classroom. Journal of International Education Research (JIER). https://doi.org/10.19030/jier.v9i3.7894

Okuyan, B. S., Sezgin, A., \& Sezgin, E. K. (2018). Associate Degree Students' Self-Efficacy Beliefs about English Language Proficiency: The Department of Hotel, Restaurant and Catering Services at Davutlar Vocational School. In H. Arslan, R. Dorczak, \& D. U. Alina-Andreea (Eds.), Educational Policy and Research (1st ed., pp. 1-551). Jagiellonian University Institute of Public Affairs.

Oxford, R., \& Shearin, J. (1994). Language learning motivation: Expanding the theoretical framework. In Modern Language Journal, 78(1), 12. https://doi.org/10.1111/j.1540-4781.1994.tb02011.x

Poehner, M. E., \& Lantolf, J. P. (2013). Bringing the ZPD into the equation: Capturing L2 development during Computerized Dynamic Assessment (C-DA). Language Teaching Research, 17(3), 323-342. https://doi.org/10.1177/1362168813482935

Raoofi, S., Gharibi, J., \& Gharibi, H. (2017). Self-efficacy and Its Relation to ESL Writing Proficiency and Academic Disciplines. International Journal of Applied Linguistics and English Literature. https://doi.org/10.7575/aiac.ijalel.v.6n.5p.127

Richard, J. P. J. (2018). Academic capital, learner goals, achievement orientations, perceptions of English, and effort: A mixed-methods study. In Dissertation Abstracts International Section A: Humanities and Social Sciences.

Ryan, S. (2010). The ideal L2 selves of Japanese learners of English. English.

Schmidt, F. L., Le, H., \& Ilies, R. (2003). Beyond Alpha: An Empirical Examination of the Effects of Different Sources of Measurement Error on Reliability Estimates for Measures of Individual Differences Constructs. Psychological Methods. https://doi.org/10.1037/1082-989X.8.2.206

Schunk, D. H. (1991). Self efficacy and academic motivation. Educational Psy, 26, 207-231. https://doi.org/DOI $10.1207 / \mathrm{s} 15326985 \mathrm{ep} 2603 \& 4 \_2$

Schunk, D. H. (2003). Self-efficacy for reading and writing: Influence of modeling, goal setting, and self-evaluation. Reading and Writing Quarterly. https://doi.org/10.1080/10573560308219

Schunk, D. H., \& Zimmerman, B. J. (1997). Social origins of self-regulatory competence. Educational Psychologist. https://doi.org/10.1207/s15326985ep3204_1

Schwinger, M., Steinmayr, R., \& Spinath, B. (2009). How do motivational regulation strategies affect achievement: Mediated by effort management and moderated by intelligence. Learning and Individual Differences. https://doi.org/10.1016/j.lindif.2009.08.006

Shi, L. (2016). Empirical study on learners' self-efficacy in ESL/EFL context. College Student Journal, 50(3), 454-465.

Shih, H. J. (2019). L2 Anxiety, Self-Regulatory Strategies, Self-Efficacy, Intended Effort and Academic Achievement: A Structural Equation Modeling Approach. International Education Studies. https://doi.org/10.5539/ies.v12n3p24

Shvay, R., Morska, N., \& Kalynyak, B. (2021). The Application of Methods for Creative Development of Personalities in Natural Sciences in Studying Foreign Languages for Specific Purposes. International Journal of Higher Education, 10(3), 119. https://doi.org/10.5430/ijhe.v10n3p119

Stewart, E. B. (2008). School structural characteristics, student effort, peer associations, and parental involvement: The influence of school- and individual-level factors on academic achievement. Education and Urban Society. https://doi.org/10.1177/0013124507304167

Swanson, P. (2014). The Power of Belief: Spanish Teachers' Sense of Efficacy and Student Performance on the National Spanish Examinations. Hispania, 97(1), 5-20. https://doi.org/10.1353/hpn.2014.0015

Sweet, A. P., \& Snow, C. E. (Eds.). (2003). Rethinking Reading Comprehension. Guilford Press.

Thang, S. M., Ting, S. L., \& Jaafar, N. M. (2011). Attitudes and motivation of Malaysian secondary students towards learning english as a second language: A case study. In 3L: Language, Linguistics, Literature. 
Utami, N. D., Regina, \& Wardah. (2015). An analysis on students'effort to improve speaking skill. Jurnal Pendidikandan Pembelajaran, 4(3), 1-10.

Viswesvaran, C., Ones, D. S., Schmidt, F. L., Le, H., \& Oh, I. S. (2014). Measurement Error Obfuscates Scientific Knowledge: Path to Cumulative Knowledge Requires Corrections for Unreliability and Psychometric Meta-Analyses. Industrial and Organizational Psychology. https://doi.org/10.1111/iops.12186

Wu, S. H., \& Alrabah, S. (2020). Harnessing text structure strategy for reading expository and medical texts among EFL college students. International Journal of Higher Education, 9(5), 36-45. https://doi.org/10.5430/ijhe.v9n5p36

Zimmerman, B. J., \& Risemberg, R. (1997). Becoming a self-regulated writer: A social cognitive perspective. Contemporary Educational Psychology. https://doi.org/10.1006/ceps.1997.0919 


\section{Appendix A}

\section{New General Self-Efficacy Scale}

1. I will be able to achieve most of the goals that I have set for myself.

2. When facing difficult tasks, I am certain that I will accomplish them.

3. In general, I think that I can obtain outcomes that are important to me.

4. I believe I can succeed at most any endeavor to which I set my mind.

5. I will be able to successfully overcome many challenges.

6. I am confident that I can perform effectively on many different tasks.

7. Compared to other people, I can do most tasks very well.

8. Even when things are tough, I can perform quite well.

\section{Appendix B}

\section{Language Learning Self-Efficacy Scale}

1. I believe in my ability to learn English as a foreign language.

2. I expect to succeed in acquiring a foreign language.

3. I believe in my ability to cope with difficulties when learning a second language.

4. I'll efficiently deal with reading comprehension questions in English.

5. Learning English as a foreign language in the past was a positive experience for me.

\section{Appendix C}

\section{EFL Reading Comprehension Effort Scale}

1. I read English as a foreign language (books, newspapers, magazines).

2. I watch foreign movies in English without translation.

3. I speak English with native English speakers.

4. I write in English (e-mails, papers, etc.).

5. I am exposed to English at work/ school, etc.

\section{Copyrights}

Copyright for this article is retained by the author(s), with first publication rights granted to the journal.

This is an open-access article distributed under the terms and conditions of the Creative Commons Attribution license (http://creativecommons.org/licenses/by/4.0/). 